\title{
Preface
}

In this book I have tried to do two things: (1) to discuss how U.S. government policies affect people's incomes and the overall income distribution, and (2) to explore what political factors make government policies take the shape they do. The first task involves reviewing and commenting on a great deal of work by economists; the second belongs in the realm of political science.

The book was written for anyone interested in how and why government policies affect ordinary citizens. It is intended for general readers as well as for students and scholars. Every effort has been made to use clear language and to explain technical terms when they come up.

Still, the subject matter is inherently complicated; government affects people in a wide variety of direct and indirect ways. It is impossible to discuss some of these effects (tax incidence, e.g., or the overall incidence of fiscal policy, or equilibrium effects of regulation, or the common law of property) faithfully, without writing some passages that some readers will find difficult. In such cases I would urge the reader to forge ahead, to get the general drift and perhaps return later to the difficult passage, but not to let it distract him or her from the main arguments.

I have used notes to support some specific points and also as guides to further reading. It is of course impossible to cite all the many relevant works; I have noted those I consider most impor- 
tant or most representative, with (naturally) an emphasis on those I find most nearly correct. I have tried to cite the strongest arguments against my positions, as well.

In some ways this project began in the academic year 19721973 when I was a Social Science Research Council post-doctoral fellow in economics at MIT and Harvard. Lester Thurow and Herbert Gintis, in particular, helped kindle my interest in economic inequality, and I was exposed to the teachings of Paul Samuelson, Kenneth Arrow, Jerome Rothenberg, and others on microeconomic theory and welfare economics.

I did much of the work on the book (considerably later) during several summers and one academic year in residence at the Institute for Research on Poverty at the University of Wisconsin, Madison. I am most grateful to the institute and especially to its director at that time, Irwin Garfinkel, for financial and other support. Many economists, political scientists, sociologists, and others in the lively intellectual setting of the Poverty Institute contributed ideas and criticisms, and Scott Milliman provided energetic and able research assistance. Needless to say, the arguments and conclusions are my own and do not necessarily reflect the views of anyone at the Poverty Institute.

In writing the book I also engaged in long dialogues (some real and some imaginary) with economist and political scientist colleagues at the University of Chicago, whose respective concerns with efficiency and equity and with markets and politics helped sharpen my own thinking.

While the book was in press, I spent a very pleasant and fruitful year as a National Fellow at the Hoover Institution, Stanford, working on a project concerning relationships between public opinion and policy making. Although I am very grateful to the Hoover Institution for supporting my other work, it would be quite incorrect to associate the arguments I make in this book with that institution.

I am grateful to many people for making comments, criticisms, and suggestions on part or all of various drafts of the book. I especially want to thank Christopher Jencks, Joseph Minarik, and Sheldon Danziger for commenting on an earlier draft of the entire book. They stimulated many improvements-though not, perhaps, as many as they would like. 
Among those who made helpful comments on one or more chapters, I want to thank Robert Lampman, Brian Barry, Charles Anderson, Jane Mansbridge, Richard Merelman, Murray Edelman, Irwin Garfinkel, Robert Haveman, Paul Menchik, Timothy Smeeding, Ted Marmor, John Bishop, Barbara Wolfe, Richard Burkhauser, Peter Eisinger, Russell Hardin, Duncan Snidal, Ira Katznelson, Roger Noll, Douglas Hibbs, and Alex Hicks. Responsibility for the product and its defects, of course, is mine.

Finally, I want to thank Mary, Benjamin, Alexandra, and Timothy, who have been very patient with a long and sometimes painfully intense writing process. I hope the book's account of my egalitarian arguments will be more convincing to them than the dinner-table versions sometimes seemed to be.

Stanford, California

Benjamin I. Page

May 1982 

It is evident that any transference of income from a relatively rich man to a relatively poor man of similar temperament, since it enables more intense wants to be satisfied at the expense of less intense wants, must increase the aggregate sum of satisfactions. ${ }^{1}$

\section{Why Equality}

The question of who gets what from government could mean many different things, depending upon how one chooses to group the population. We might want to know how government actions affect blacks as compared with whites, or the young contrasted to the old, or residents of the Northeast versus the Southwest, for example. This book, while it does touch on such matters, is mostly concerned with what the U.S. government (federal, state, and local) does for high-income people as compared with those of low income-or, to put it loosely, what benefits go to the rich and what to the poor.

The focus is on inequality of income. In this first chapter, I will discuss some reasons why equality is desirable, show that private wealth and income in the United States are very unequally distributed, and suggest government as the place to look for redistribution. The rest of the book deals with what effects the government actually has on inequality and why, politically, it has the effects it does.

Equality, of course, is not cherished by everyone, especially not by those who are at the top of the heap and want to stay there. The last several centuries of world history have seen a gradual breakdown of rigid inequalities in status based on race, sex, class, ethnicity, and the like. Equality of political and legal 